\title{
Advanced Manufacturing Technologies in Russia: Outlines of a New Policy
}

\author{
Irina Dezhina, Alexey Ponomarev, Alexander Frolov
}

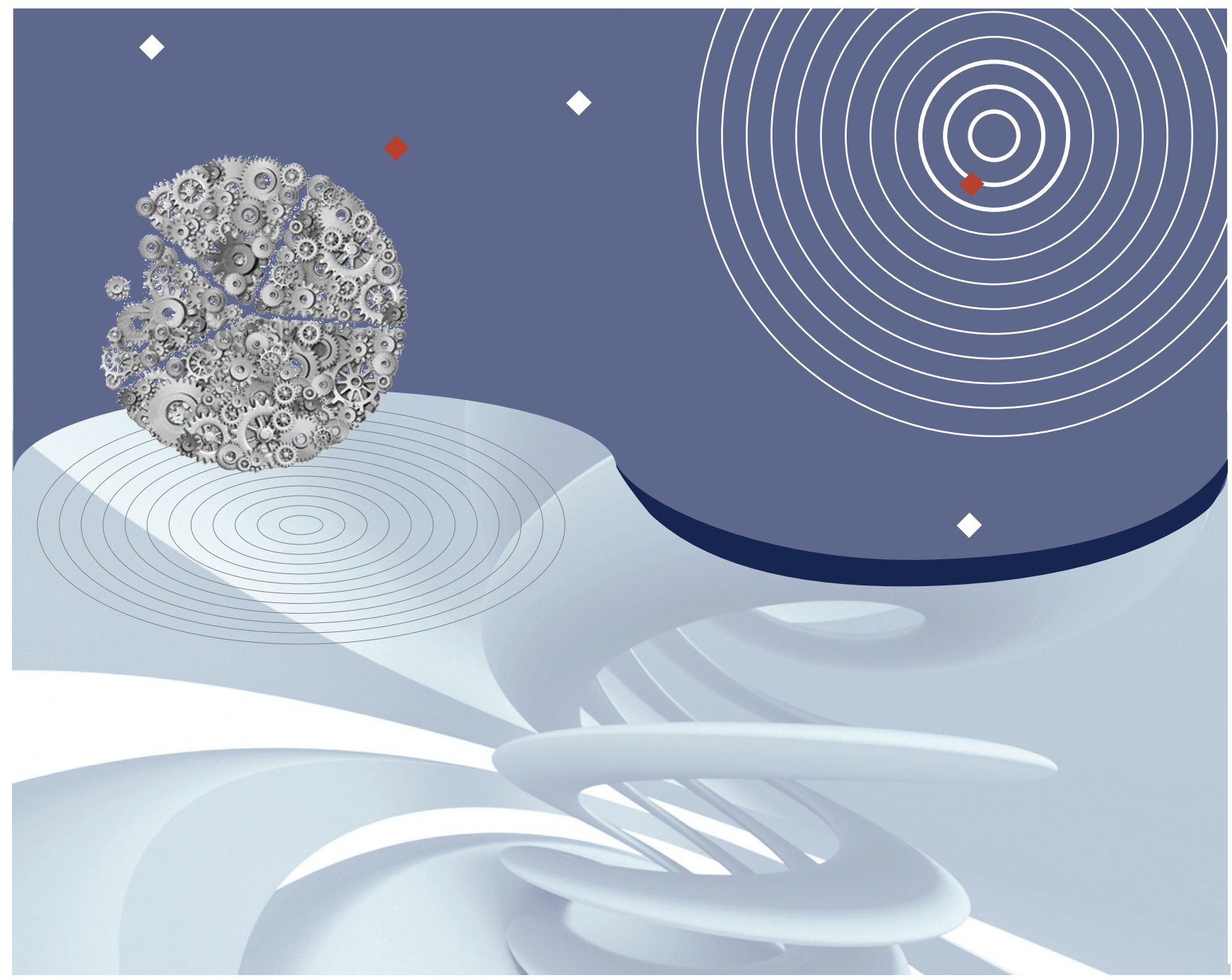

The present article, which continues the discussion of advanced manufacturing technologies initiated in Foresight-Russia issue 2 (2014) [Dezhina, Ponomarev, 2014], evaluates the current state of this field in Russia. The analysis here examines the state of the relevant scientific research and the readiness of industry to adopt the new technologies developed by researchers.

The study is based on bibliometric and patent analyses, as well as on expert evaluations of the markets related to different segments of advanced manufacturing.
Irina Dezhina - Head of Research Group on Science and Industrial Policy. E-mail: i.dezhina@skoltech.ru

Alexey Ponomarev - Vice President for Industrial Cooperation and Public Programs. E-mail: ponomarev@skoltech.ru

Alexander Frolov - Analyst on Industrial Policy.

E-mail: a.frolov@skoltech.ru

Skolkovo Institute of Science and Technology

Address: 100, Novaya str., Skolkovo, Odintsovsky district,

Moscow Region, 143025, Russian Federation

\section{Keywords}

advanced manufacturing; state science and innovation policy; bibliometric analysis; patent analysis; demand; project consortia

DOI: $10.17323 / 1995-459 X .2015 .1 .20 .31$ 
M any countries are paying considerable attention to advanced manufacturing technologies (AMTs), and in 2013 the Russian Government followed this trend in turning its gaze to such technologies. This interest is not so much a question of fashion but of real economic needs.

Advanced manufacturing technologies are a comparatively new priority of state innovation policy, even for developed countries. In Russia, where this field has been studied for some time both theoretically and statistically [HSE, 2014b, p. 398], it has taken on new meaning and has expanded considerably in the last two years. The bulk of material on the mass customization of AMTs is analytical reports by consultancy firms, not academic research. Among these are works by the 'Severo-Zapad' strategic development centre (Severo-Zapad SDC) and Strategy Partners Group (SPG). The studies of the former focus on large-scale, long-term changes in Russian industry brought about by advances in AMTs. The Foresight studies by Severo-Zapad SDC have predicted three consecutive technological revolutions that will take place in Russia in the coming decades [Knyaginin, 2011]:

- 2013-2020: a mass transition to modern design and life cycle management systems - the 'modular revolution';

- 2013-2020: the introduction of automated design of material functions and properties;

- 2020-2035: the development of next-generation smart environments.

In turn, SPG has concentrated on analysing the impact of AMTs on the production chain [Idrisov, 2011; Idrisov, Grigoryev, 2012]. In particular, their studies looked at the sub-optimal organizational structure of mechanical engineering as a barrier to the development of the industry. SPG remarked that AMTs contribute to decentralization and growth in the innovative potential of small and medium enterprises, meaning that they weaken the competitiveness of domestic mechanical engineering companies, where high levels of vertical integration are common.

Studies devoted to the different AMT segments in Russia, including new materials [Labykin, 2014a], 3D printers [Labykin, 2014b], robotics [Efimov, 2014], and laser equipment [Saprykin, 2014], are examples of the different directions being taken. They outline specific market parameters (value, share of Russian producers) and the positions of key players in the industry.

Recent publications by Yuriy Simachev, Kseniya Gonchar and Andrei Yakovlev examine the innovative behaviour of companies and the impact of various innovation incentive mechanisms (with no special focus on AMTs). They have assessed the dynamics and specific nature of the innovation process in manufacturing companies using constantly updated empirical material [Gonchar, 2009; Golikova et al., 2012; Yakovlev, 2014]. These researchers have also analysed the effectiveness of various state innovation policy instruments [Ivanov et al., 2012; Dezhina, Simachev, 2013]. They also touch on more general issues relating to the implementation of industrial policy, taking into account the impact of different interest groups [Simachev et al., 2014]. The authors of the aforementioned studies noted the lack of favourable conditions for industrial policy in Russia and the relevance of specific initiatives to search for more effective regulatory instruments.

Studies by the Institute for Statistical Studies and the Economics of Knowledge (ISSEK) at HSE [Gokhberg et al., 2011; HSE, 2014a] occupy a special position in research on state innovation policy, the state of supply and demand for technologies and the key technology trends in Russia and worldwide. Researchers at ISSEK have focused predominantly on identifying and developing policy measures to support Russia's science and technology priorities. Given that AMTs were only recently included among the state's technology priorities, ISSEK 
Table 1. Key advanced manufacturing technology segments and examples

\begin{tabular}{|c|c|c|c|}
\hline \multicolumn{2}{|c|}{ AMT segments } & $\begin{array}{l}\text { Traditional techniques and } \\
\text { technologies (examples) }\end{array}$ & $\begin{array}{l}\text { New techniques and technologies } \\
\text { (examples) }\end{array}$ \\
\hline \multirow{2}{*}{$\begin{array}{l}\text { ICT systems to support } \\
\text { the product life cycle }\end{array}$} & $\begin{array}{l}\text { Multi-dimensional modelling } \\
\text { of complex articles }\end{array}$ & \multirow{2}{*}{ CAD/CAE/CAM, PDM } & \multirow{2}{*}{$\begin{array}{l}\text { CAx for additive technologies, } \\
\text { cloud technologies, M2M }\end{array}$} \\
\hline & $\begin{array}{l}\text { Intelligent production } \\
\text { management systems }\end{array}$ & & \\
\hline \multicolumn{2}{|c|}{ Equipment and technologies to form articles } & $\begin{array}{l}\text { Machine tool industry, plastics } \\
\text { processing equipment, etc. }\end{array}$ & $\begin{array}{l}\text { Additive production, laser } \\
\text { processing }\end{array}$ \\
\hline \multicolumn{2}{|c|}{$\begin{array}{l}\text { Equipment and technologies to automate production } \\
\text { processes }\end{array}$} & $\begin{array}{l}\text { Relays, switches, sensors, power } \\
\text { electronics }\end{array}$ & Industrial robotics, sensor systems \\
\hline \multicolumn{2}{|c|}{ Advanced materials used for new production processes } & Metals, plastics & $\begin{array}{l}\text { Composite materials, metals, } \\
\text { ceramics, etc. }\end{array}$ \\
\hline
\end{tabular}

studies have only indirectly touched on them. At the same time, ISSEK publishes a large amount of empirical data, including data on the manufacturing industry and the impact of various state regulatory instruments on the industry [Gokhberg et al., 2014]. As such, despite the relative novelty of AMTs for Russia, closely related fields that are linked to the development of the manufacturing industry as well as state innovation policy, have been studied in some depth.

Our study continues a theme previously analysed by the authors [Dezhina, Ponomarev, 2014]. While we proposed a definition of AMTs in this first article together with a summary of foreign experience in supporting this sector, in the present study we have tried to apply the concept and hone down the segmentation of AMTs (Table 1). The article focuses on the level of supply and demand for AMTs, alongside policies to support advanced manufacturing in Russia. We use the following definition of AMTs:

Advanced manufacturing technologies are a set of processes to design and produce, at a sophisticated technological level, customized (individualized) material objects (goods) of varying complexity, the cost of which is comparable with the cost of mass production goods [Dezhina, Ponomarev, 2014].

\section{Science as a driving force for the development of advanced manufacturing technologies}

To assess the scale of research and development (R\&D) in the field of AMTs in Russia, we analysed publication activity using the international Web of Science (WoS) database and the Russian Scientific Citation Index (RSCI). The bibliometric data extracted from these databases were used to summarize data on two different types of research and development (R\&D) - data accessible to the international scientific community and data geared predominantly towards a Russian-speaking professional audience. The data obtained chronologically from WoS are limited to a timeframe between January 2000 and September 2014, when it is widely recognized that there was a surge in interest in AMTs abroad. The timeframe for the RSCI covers its entire existence from 1991 to September 2014. The readiness of R\&D results to be commercialized was assessed on the basis of data from the company Questel - Orbit for 20 years from September 1991 to September 2014. ${ }^{1}$

Analysis shows high developmental dynamics in all areas of AMTs in leading industrial countries and continuing high levels of research and engineering activity over the last decade. Many technological areas have advanced beyond the realm of university laboratories, having gained a fresh impetus in the research divisions of major industrial companies. The fact that it is predominantly

\footnotetext{
1 The database work was carried out by a team in the Centre of Scientific and Technological Expertise at the Russian Presidential Academy of National Economy and Public Administration (RANEPA) at the request of the Skolkovo Institute of Science and Technology.
} 
Figure 1. Number of publications on RSCI according to advanced manufacturing

technology type over the period 1991-2014

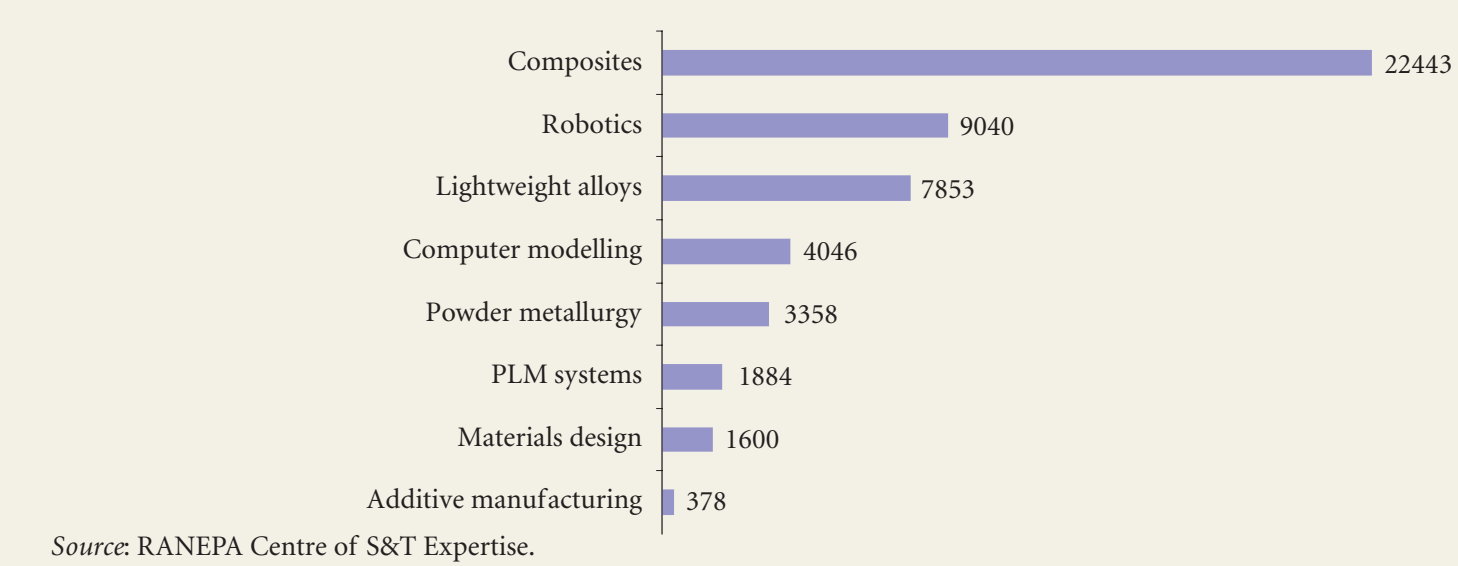

large-scale industrial companies accounting for up to $50 \%$ of all patents issued worldwide that are in the top 30 patent holders in each AMT segment serves as confirmation of this. Against this backdrop, publication and patent activity by Russian research centres and companies looks far more modest. This indicates the lack of competitive undertakings that are capable, in the short-term (5-7 years), of securing the country's leadership in certain areas of industrial manufacturing. The highest publication activity figures for Russian specialists on WoS are recorded for 'Powder metallurgy and new alloys' (under 'New materials for AMTs'), with a little more than $2 \%$ of all publications worldwide. For such an important, defining aspect of new manufacturing directions as the use of information technologies (IT) for product life cycle management (PLM systems), the percentage is only $0.07 \%$.

However, RSCI data paint a different picture. While the largest number of publications in both research publication databases is seen in fields such as 'Composites' and 'Robotics', is fundamentally different in other areas the situation (Figures 1 and 2). Placed third in terms of publication numbers on RSCI is 'Lightweight alloys', which could be explained by the dual purpose of a significant number of technologies falling in this group. In computer-aided material design and additive manufacturing, conversely, the proportion of publications in international journals is lower than in Russian journals, which is linked to the relative novelty of such technologies and the prevalence of fundamental $R \& D$, the results of which are published intensively in Russian-language scientific articles. However while the institutes of the Russian Academy of Sciences (RAS)

Figure 2. Number of publications on Web of Science according to advanced manufacturing technology type over the period 2000-2014

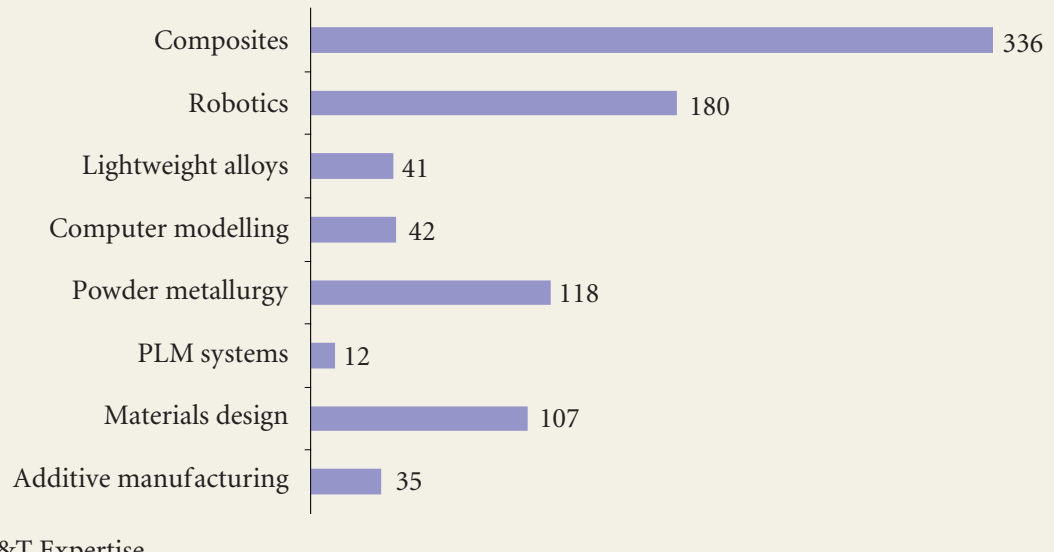

Source: RANEPA Centre of S\&T Expertise. 


\section{Table 2. Indicators of advanced manufacturing technology development in Russia (based on scientometric and patent analysis of data from Web of Science for the period 2000-2014 and Orbit for the period 1994-2014)}

\begin{tabular}{|c|c|c|c|c|}
\hline Name of technology & $\begin{array}{c}\text { Proportion of patents } \\
\text { issued in the Russian } \\
\text { Federation with a } \\
\text { Russian focus in the } \\
\text { Orbit global database } \\
(\%)\end{array}$ & $\begin{array}{l}\text { Proportion of } \\
\text { patents issued to } \\
\text { foreign applicants } \\
\text { as a percentage of all } \\
\text { patents in the Russian } \\
\text { Federation }(\%)\end{array}$ & $\begin{array}{c}\text { Number of } \\
\text { triad patents } \\
\text { with a Russian } \\
\text { focus }\end{array}$ & $\begin{array}{l}\text { Leading technology } \\
\text { countries }\end{array}$ \\
\hline Industrial and service robotics & 2.83 & 28.23 & 1 & Japan, USA, China \\
\hline Powder metallurgy and new alloys & 2.28 & 51.47 & 1 & $\begin{array}{l}\text { Japan, China, USA, South } \\
\text { Korea, Germany }\end{array}$ \\
\hline $\begin{array}{l}\text { Lightweight alloys for the aviation } \\
\text { and automotive industry }\end{array}$ & 2.00 & 73.90 & 1 & $\begin{array}{l}\text { Japan, USA, Germany, } \\
\text { China }\end{array}$ \\
\hline $\begin{array}{l}\text { Composites, 'hierarchical' } \\
\text { materials }\end{array}$ & 1.87 & 80.61 & 9 & $\begin{array}{l}\text { France, Germany, USA, } \\
\text { Japan, China }\end{array}$ \\
\hline $\begin{array}{l}\text { Computer technologies to model } \\
\text { and manufacture articles }\end{array}$ & 0.81 & 47.88 & 0 & $\begin{array}{l}\text { USA, Japan, China, South } \\
\text { Korea }\end{array}$ \\
\hline $\begin{array}{l}\text { Information technologies for } \\
\text { production cycle management }\end{array}$ & 0.58 & 80.00 & 0 & $\begin{array}{l}\text { USA, Japan, China, South } \\
\text { Korea }\end{array}$ \\
\hline $\begin{array}{l}\text { Computer-aided design to develop } \\
\text { new materials with specific } \\
\text { properties }\end{array}$ & 0.30 & 94.00 & 0 & $\begin{array}{l}\text { China, USA, Japan, South } \\
\text { Korea }\end{array}$ \\
\hline Additive manufacturing & 0.14 & 89.31 & 0 & $\begin{array}{l}\text { South Korea, Japan, USA, } \\
\text { China }\end{array}$ \\
\hline
\end{tabular}

lead the way according to bibliometric data on WoS, universities have complete superiority according to RSCI data.

Six countries act as technological drivers, leading the way in terms of the number of patents and triad patent families: USA, Japan, and China, followed by South Korea, Germany, and France. In Russia, the proportion of patents obtained by residents for technological solutions relating to advanced manufacturing technologies was critically low, especially in the field of additive manufacturing $(0.14 \%)$ and computer-aided design for intensive development of new materials with specific properties $(0.30 \%)$. The disproportionately high share of foreign patent applicants in the total number of patents registered in the country is clear over most of the broad spectrum of AMTs (Table 2). As such, nonresidents (chiefly companies) own $89 \%$ of patents for additive manufacturing solutions. Most threatening to the country's technological interests is the situation in computer-aided design using theoretical models and databases, where $94 \%$ of Russian patents have been issued to foreigners. It is not so much the low proportion of Russian publications and patents that is alarming (this can be explained by the low level of internationalization) as much as the lack of national technology drivers in publicly owned industrial companies. Engineering companies, small and medium (but not large) enterprises, academic research institutes, and leading universities are occupying the upper echelons in Russian patent holder ratings.

The results of a scientometric and patent analysis in the AMT sector do not always coincide with expert assessments. This divergence is explained by the fact that publication activity by workers at research institutes and higher education institutions has only recently started to become visible. As a result, the correlation between R\&D quality and their representativeness in international publications databases is far from perfect. The RSCI is actually continuing to accumulate a critical amount of information and, despite the length of its existence, has not reached a level of stable operation. The shortcomings of this database continue to be the subject of ongoing discussions in the scientific community. The RSCI is being improved but still cannot be seen as a source of reli- 
able bibliometric information. The limitations of RSCI are also linked to the data analysis methods it uses. Descriptions of the subject areas were drawn up on the basis of primary and secondary key words and word combinations formulated by experts. Ultimately, bibliometric data and patent statistics are dependent on how accurately the relevant field has been delineated. For instance, a significant number of publications on composites can in part be accounted for by including terms with the root 'nano' in their list of key words ('nanotubes', 'nanomaterials' etc.), which has caused a significant increase in figures in view of the fashionable nature of nanotechnology over the last eight years i.e. since the state created the Russian Nanotechnology Corporation (Rosnano) in 2007.

Overall, despite some limitations with the scientometric analysis, it can be argued that Russia has only fragmentary world-class scientific capacity in the field of AMTs.

\section{Readiness of Russian industry to develop and implement advanced manufacturing technologies}

The lack of widely accessible statistics for the AMT sector prevents an in-depth analysis of Russian supply and demand for AMT products and solutions. Expert assessments almost entirely replace such statistics, which fragments the overall picture. In the majority of AMT areas on the domestic market, foreign companies tend to dominate. At the same time, in some fields, Russian players have managed to consolidate on the domestic market and even on foreign markets in several areas.

\section{Statistical picture: troubled contours}

Official statistical data on AMTs come from the Russian Federal State Statistics Service (Rosstat), foreign economic activity databases (TN VED), and various company databases (such as SPARK). Rosstat data are only available for the machine tools industry; the remaining industries are too specialized to have their own nomenclature with the federal statistics service. More detailed information is available from customs statistics (Table 3).

Unfortunately, even TN VED does not make it possible to specify data for certain types of AMT (3D printers, carbon fibres and articles made from carbon fibre, etc.) as it uses 10-digit industry codes. Business databases (such as SPARK) are not of much use for our purposes either as when selecting companies, it operates using key activity types which do not coincide with AMT areas. Even simple statistics based on the revenue of key players in certain industries are not

\section{Table 3. Export and import volumes for each market linked to advanced manufacturing} technologies, in 2013 (millions of US dollars)

\begin{tabular}{|c|c|c|c|c|}
\hline Product groups & TN VED Codes & Import & Export & $\begin{array}{l}\text { Import-export } \\
\text { ratio (times) }\end{array}$ \\
\hline Machines (total) & $8456-8466$ & 2839 & 100 & 28 \\
\hline \multicolumn{5}{|l|}{ Of which: } \\
\hline Laser & 845610 & 83 & 3 & 25 \\
\hline For non-metallic articles processing & $8464-8465$ & 650 & 5 & 119 \\
\hline Parts and accessories & 8466 & 309 & 28 & 11 \\
\hline $\begin{array}{l}\text { Equipment to process resins and plastics, furnaces and } \\
\text { chambers, welding machines, moulding flasks, casting } \\
\text { machines, metal rolling cylinders and mills }\end{array}$ & $\begin{array}{l}8454,8455,8477,8480 \\
8514,8515\end{array}$ & 2767 & 142 & 20 \\
\hline Control and operation devices & $9024-9032$ & 3383 & 865 & 4 \\
\hline $\begin{array}{l}\text { Carbonaceous materials, fibre glass and fibre glass } \\
\text { articles, epoxy resin }\end{array}$ & $390730,681510,7019$ & 342 & 147 & 2 \\
\hline Industrial robots & 847950 & 41 & 1 & 70 \\
\hline Total & & 10414 & 1292 & 8 \\
\hline
\end{tabular}

Source: TN VED database. 
reliable as a significant proportion of corporate income cannot be attributed to a certain market, and the revenue structure in databases is not fixed.

Industry associations or consultancy firms (Gardner, CIMdata, Wohlers Associates, IFR, etc.) carry out assessments of AMT markets abroad. In Russia, the role of such institutions in the systematic collection and analysis of statistics is still minimal. Therefore, government departments commission specialist studies to analyse specific technological fields and markets; ${ }^{2}$ the clients then have to rely on these results, which are of ten judgement-based (Table 4).

The data set out in table 4 show that in the majority of industries linked to AMT developments, the situation is difficult, characterised by the dominance of foreign companies. This applies to both traditional (machine tools) and new manufacturing (3D printers). Russian players only occupy strong positions (approximately $30 \%$ market share) in the laser manufacturing and sof tware engineering industries.

\section{Niche competitiveness and low demand as barriers: expert assessments}

Expert assessments of the level of AMT development in Russian industry correspond on the whole with the statistical assessments provided above. Thus, the best positions are held by Russian players on the sof tware engineering and new materials markets: these players are not only successfully developing domestically but are also actively participating in international projects, supporting a technological level of manufacturing close to global standards. Among the leading group of companies in the software engineering field are ASKON, DATADVANCE, Ledas, CompMechlab, the Russian Federal Nuclear Centre AllRussian Research Institute of Experimental Physics, and Fidesis. The main players on the new materials market are Unikhimtek, ApATeK, and the Federal State Unitary Enterprise Central Research Institute of Structural Materials 'Prometey', among others. ${ }^{3}$

Russian companies are virtually absent from the manufacture of end products in the robotics industry. Despite the general lag in this area, certain companies are offering competitive technical solutions (Vist Mining Technologies, Eidos Robotics, and others). Production of 3D printers is at an initial stage. New companies in this field have recently started to appear for the first time in Russia

\section{Table 4. Value of markets linked to manufacturing products in the field of advanced manufacturing technologies, in Russia and the share of Russian companies in such markets in 2012*}

\begin{tabular}{|c|c|c|}
\hline Market & $\begin{array}{l}\text { Market value (millions } \\
\text { of US dollars) }\end{array}$ & $\begin{array}{l}\text { Share of Russian } \\
\text { companies }(\%)^{\star}\end{array}$ \\
\hline Machine tool industry (metal working) & $1712^{\star *}$ & 5 \\
\hline of which lasers & $332^{* *}$ & 26 \\
\hline Sof tware engineering (mCAD, mCAM, mCAE, cPDM, etc.) & 205 & 30 \\
\hline 3D printers & $<3$ & $<5$ \\
\hline Industrial robotics & 40 & $<5$ \\
\hline Composite materials & $<350$ & 20 \\
\hline
\end{tabular}

\footnotetext{
2 See, for example, the project to appraise the sof tware engineering market in Russia carried out by the SeveroZapad strategic development centre at the request of the Russian Ministry of Industry and Trade (available at: http://prom.csr-nw.ru/about, accessed 26.01.2015).

${ }^{3}$ Expert assessments were obtained during the preparation of a public analytical report by the Skolkovo Institute of Science and Technology on the science and technology development priority 'New manufacturing technologies' at the request of the Russian Ministry of Education and Sciences (November 2014). The survey only covered 69 experts, representing different AMT areas (ICT, advanced materials, robotics, additive manufacturing), potential client companies for these technologies, development institutions and government departments.
} 
(Picaso-3d, OAO Centre for Additive Technology Skills, the Central Research Institute of Machine Building Technology, etc.)

Regarding the use of advanced technologies by organizations and manufacturing departments, experts have noted the high level of uptake by Russian enterprises of software engineering and other PLM (Product Lifecycle Management) system elements. At the same time, a key factor continues to be the fragmentation of different business processes, which makes it harder to not only collaborate with different businesses in the manufacturing chain but also work with branches of major integrated structures.

Alongside more general problems such as expensive credit resources and the shortage of highly qualified personnel, the development of Russian companies in the field of AMTs is being held back by an imbalance typical of the market, linked - on the one hand - to a shortage in demand and - on the other hand - to the lack of several important technology skills. The challenge of stimulating demand is not a simple matter of solvency, but rather involves overcoming a low motivation to modernize and high levels of monopolism, encouraging technological competition (which currently takes place mostly outside the technological plane), reducing the conservative regulation of public contracts, and extending the planning horizon. The development of innovative development programmes by publicly owned companies goes some way to mitigating the impact of the above-listed negative factors.

From the viewpoint of increasing supply, companies' capabilities are limited by the lack of a 'platform' or other key technologies. These technologies determine the competitiveness of an entire class of complex products using AMTs yet cannot be developed by a single small innovation company alone (for example, a 3D kernel for computer engineering).

Thus, the development of AMTs in Russia is hindered by stagnating demand amid a general decline in economic growth, a worsening investment climate, and the particular way in which the activities of monopolies and publicly owned companies are regulated. The sector is also affected by the lack (or underdevelopment) of the necessary technological groundwork which is caused by the low priority given to AMTs by $\mathrm{R} \& \mathrm{D}$ funding from various state and non-state sources. At the same time, despite Russia's high overall dependency on imports, there are still scatterings of skills in several AMT segments and potential opportunities for expansion. Stimulating the development of this sector requires coordinated efforts from the state and business to spur on and establish competitive supply.

\section{Evolution of state instruments to support links between science and business}

Russia has accumulated a wealth of experience and various instruments to stimulate links between scientific organizations and industrial enterprises; previous experience in this area is very important for the development of AMT sector. The first state innovation projects were initiated by the Russian Ministry of Industry, Science and Technology back in 2002. ${ }^{4}$ These large-scale projects brought together representatives of the scientific and industrial spheres to solve key problems concerning the competitiveness of Russian technological products, including trying to lower the cost of manufacturing through cost-effective use of resources. Due to the significant budgetary funding (from 0.7 to 2 billion roubles for each project) and the involvement of some of the largest Russian companies, the initiatives have been referred to as 'megaprojects'.

\footnotetext{
${ }^{4}$ Order of the Russian Ministry of Industry and Science 'On the organization of work at the Russian Ministry of Industry and Science to prepare proposals on projects (programmes) of special state importance' no 22 dated 11.02.2002.
} 
The results of these megaprojects are varied. Official figures show that they are effective from a financial perspective. Moreover, some have resulted in positive effects that are significant in light of the development of AMTs. In particular, new forms of project management have been introduced by outsourcing a number of administrative duties to foreign companies [Dezhina, 2008, p.119]. A serious shortcoming of this tool, however, lies in the fact that R\&D was financed by federal budget funds paid directly to research institutes and higher education institutions. The companies, in whose interests the work was carried out, only wanted to commercialize the results. As such, the links between the scientific structures and the companies (the customers of the R\&D) who were accountable to the government (the R\&D funder) were mediated and more complex. Later, in 2010, this process was optimized by using subsidies to businesses to finance complex high-tech manufacturing projects carried out jointly with higher education institutions. ${ }^{5}$ The errors of the initial megaprojects programme in 2002 were taken into account: enterprises became the recipients of the state support, and then passed on the funds to higher education institutes which carried out the R\&D.

The first results of these joint projects were revealed in 2011-2012 [Dezhina, Simachev, 2013]. This analysis showed that the largest payments from this system went to medium-sized companies interested in expanding their R\&D through the use of research and engineering collectives and through gaining access to the scientific equipment of higher education institutes. The motive of obtaining additional funding for innovation activity was important for small firms, but less so for large companies. Moreover, economies of scale played an important role in networking: cooperation lasting for more than one year and expanding the composition of participants (scientific and industrial organizations) proved to be the most effective.

Alongside direct (including financial) state support for collaboration between $\mathrm{R} \& \mathrm{D}$ actors and manufacturing in the field of AMTs, infrastructure projects aimed at developing small, science-intensive business have been particularly important. One of the biggest in scale and one of the longest running such projects has been support for science and technology parks (STPs). In one form or another, STPs have received funding over the entire post-Soviet period. The results of a survey distributed to 17 science and technology parks (out of 35 initially selected), carried out by Ernst \& Young and the Russian Venture Company in 2014 , confirmed that only half of all science and technology parks granted access to their laboratories and specialist equipment to innovative small and medium enterprises [Ernst \& Young, RVC, 2014, p.6]. ${ }^{6}$ The majority of parks only leased out premises, including for negotiations and conferences. The end result is that resident companies have been buying expensive equipment which, as a general rule, is not used to its full capacity [Ernst \& Young, RVC, 2014, p. 14]. An analysis of programmes to create innovation infrastructure at higher education institutions ${ }^{7}$ has shown that an overwhelming number of STPs are still structural sub-divisions of universities with a maximum of three employees [Bakardzhieva, 2014].

An attempt to consolidate successful STPs in the form of an 'Association of High-tech Science and Technology Parks' [Association of Technology Parks, 2014] has so far only been partially successful. Just three STPs in Russia meet the requirements to join this association: the Kazan IT Park, the Novosibirsk

\footnotetext{
${ }^{5}$ Resolution of the Government of the Russian Federation 'On state measures to support the development of cooperation between Russian higher education institutions and organisations carrying out integrated projects to develop a high-tech industry' no 218 dated 09.04.2010.

6 The survey was conducted among previously surveyed (i.e. not the top performing) science and technology parks ( 17 out of the 80-90 in existence); therefore, overall, the actual figures are likely lower then presented in the survey.

${ }^{7}$ Resolution of the Government of the Russian Federation 'On state support for the development of innovation infrastructure in federal higher professional education institutions' no 219 dated 09.04.2010.
} 
Academpark, and the High-tech Technopark in the Khanty-Mansi Autonomous Okrug (or Yugra) [Bakardzhieva, 2014]. One possible model to optimize the work of STPs has been implemented in a project to create a prototype centre based in the Novosibirsk Academpark, which has been named the Technology Support Centre. Its purpose is to allow residents to quickly and cheaply develop prototypes of a new product and launch small-scale production. The centre's business model is based on the state purchasing the necessary equipment in consultation with the residents of the park and leasing it out at preferential rates. In parallel to this, small companies are being set up to provide small-scale manufacturing services, initially to larger clients, and later to a wider range of partners, thereby ensuring that the equipment is used to maximum capacity. The network of small enterprises immediately 'catering for' some of the innovative firms in the park allow for deeper collaboration and stronger ties between links of the manufacturing chain.

This approach has also been adopted in the form of engineering centres, which started to be set up from 2013 [Government of the Russian Federation, 2013] and are fitted out with the latest equipment. Roughly $50 \%$ of spending at these centres based in higher education institutions and research organizations goes on buying experimental industrial equipment; more than $20 \%$ goes on specialist software [Povalko, 2014]. The developmental history of technology infrastructure in Russia offers several examples of the successful formation of both the technological ecosystem itself and the resident companies situated within that system. Such examples can be used to broaden ties between stakeholders involved in the development of AMTs.

To date, Russia does not yet have any innovation policy instruments which meet the developmental needs of the AMT sector. At the same time, mechanisms to support collaboration between industry and research organizations and stimulate the development of the production chain through STPs can be viewed as a foundation upon which further improvements of the policy toolkit and adaptations of these tools to the specificities of developing and manufacturing products can be made.

\section{Prospective directions for support}

Our analysis of the tools used to support collaboration between research organizations and enterprises (both small and medium-sized), and our assessment of the level of preparedness of the relevant scientific research and industry for the development of AMTs allow us to recommend several trajectories for improving Russia's state policy in this field.

First. The formation of project consortia to provide targeted support to segments shaping the development of AMTs. A key element here is ensuring that there is guaranteed demand (a 'starting order') from major Russian companies or individual industries, i.e. clients taking on an obligation to purchase the technologies and/or products created by consortia when the latter achieve previously agreed technical, price or other parameters. In this respect, it is important that the demands on those performing the research are coordinated as far as possible, allowing them to concentrate their resources on achieving certain characteristics. Such cooperation could take place through the state, which would establish a set of applicable measures based on its own priorities, or without state involvement. The formation of market demand through a 'starting order' is an important factor affecting the choice of these priorities.

A central element in state support for the AMT sector is stimulating clients from all public sector companies in the economy by controlling development programmes, including forms such as 'innovative development programmes'. Another important tool continues to be the system of technical requirements in public contracts. Alternative approaches to generating 'starting orders' are possible, for instance, indirect regulation to stimulate general innovation activity 
in the economy. Project consortia could be set up based on the experience and links of existing technology platforms, especially those where both manufacturers and consumers of AMTs participate. The budgets of consortia could take on different configurations of company funds and state support, depending on the specific nature of the technologies, products, markets and the participants themselves.

Second. The formation of a coordinated $\mathrm{R} \& \mathrm{D}$ programme at the pre-competitive stage, taking into account the interests of consortia and major players involved in deciding to start AMT development. Within the scope of their respective mandates, federal departments and funds could be granted access to key R\&D results obtained by consortia members during the pre-competitive stages.

Third. The creation of prospective research centres at research institutes or higher education institutions to carry out R\&D on AMTs at the pre-competitive stage, as well as to train specialists on new areas of technological development. Centres must provide research, scientific, expert, and educational support for the science and technology activities of public and private sector companies, with a focus on small and medium businesses. Depending on economic viability, they could set up small innovative companies in line with their own profile. The assumption is that such centres would be open structures working on orders from both consortia (anchor investors) and the external market.

Fourth. Infrastructure support. Since the AMT areas described in this article lower the barriers to entry for small and medium companies (due to a focus on individualization and outsourcing), these companies are starting to become one of the supporting elements of the system to underpin the development of such technologies. The activities of small companies can be optimized by stimulating their links with local administrations, STPs, special economic zones, etc. In this respect, small companies are recognized as able to service the needs of medium enterprises, including the manufacture (even on a small scale) of required parts and components.

Regional and local administrations could work harder to develop infrastructure and support STPs by ensuring that preferential equipment lease rates are offered to small firms that provide services to medium and large companies. In addition, the small Science and Technology Business Development Support Fund and other support institutions for small businesses could develop various forms of collaboration between small, medium and large enterprises, making more active use of innovation vouchers, grants for staff retraining, etc. All of these measures would make it possible to establish a toolkit in Russia adapted to the specific needs of developing AMTs and contributing to the formation of an environment for effective collaboration between the clients and developers of AMTs in consortia and long-term research projects. R\&D in key or 'platform' technologies could serve as a scientific basis for the development of AMTs. Finally, targeted support for small and medium innovative businesses would help create and consolidate network production chains.

\section{References}

Association of Technology Parks (2014) Metodicheskie rekomendatsii 'O predmete deyatelnosti, tselyakh, zadachakh tekhnoparka, structure, upravlenii, imushchestve i sredstvakh, zemelnom uchastke, inzhenernoi infrastrukture i perechne uslug rezidentov tekhnoparka' ['About the subject of activities, goals, objectives of technopark, structure, management, property and equipment, lands, engineering structure and range of services of residents of technopark'], Moscow: Nonprofit Partnership 'Association of technology parks in the sphere of high technologies'. Available at: http://nptechnopark.ru/upload/MR.pdf, accessed 28.11.2014 (in Russian).

Bakardzhieva S. (2014) Pitomniki dlya 'gazelei'. Polnostyu li sootvetstvuyut rossiiskie tekhnoparki v sfere vysokikh tekhnologii svoemu prednaznacheniyu? [Nurseries for 'gazelles'. Do Russian industrial technoparks in the sphere of high technologies fully concur to its purpose?]. Intelligent Manufacturing, no 27. Available at: http://www.umpro.ru/index.php?page_ id=17\&art_id_1=521\&group_id_4=58, accessed 28.11.2014 (in Russian).

Creon Energy (2014) Biznes dlya 'bolshikh'. Konferentsiya 'Kompozity i kompaundy 2014' [Business for 'Giants'. The conference 'Composites and compounds 2014']. Available at: http://www.creonenergy.ru/consulting/detailConf.php?ID=110657, accessed 28.11.2014 (in Russian). 
Dezhina I. (2008) Gosudarstvennoe regulirovanie nauki v Rossii [Government regulation of science in Russia], Moscow: Master (in Russian).

Dezhina I., Ponomarev A. (2014) Advanced Manufacturing: New Emphasis in Industrial Development. Foresight-Russia, vol. 8, no 2, pp. 16-29.

Dezhina I., Simachev Y. (2013) Svyazannye granty dlya stimulirovaniya partnerstva kompanii i universitetov v innovatsionnoi sfere: startovye effekty primeneniya v Rossii [Matching Grants for Stimulating Partnerships between Companies and Universities in Innovation Area: Initial Effects in Russia]. Journal of the New Economic Association, no 3, pp. 99-122 (in Russian).

Efimov A. (2014) Razvitie robototekhniki v Rossii $i$ v mire [The development of robotics in Russia and the world]. Available at: http://izvestia.ru/news/578477, accessed 28.11.2014 (in Russian).

Ernst \& Young, RVC (2014) Problemy i resheniia: biznes-incubatory i technoparki Rossii [Problems and solutions: Business incubators and technoparks in Russia], Moscow: Ernst\&Young, RVC. Available at: http://www.ey.com/Publication/ vwLUAssets/EY-business-incubators-and-technoparks-in-russia/\$FILE/EY-business-incubators-and-technoparks-in-russia. pdf, accessed 28.11.2014 (in Russian).

Gardner Research (2014) The World Machine-Tool Output \& Consumption Survey 2014, Cincinatti, OH: Gardner Business Media, Inc. Available at: http://www.gardnerweb.com/cdn/cms/2014wmtocs_SURVEY.pdf, accessed 28.11.2014.

Gokhberg L., Kitova G., Roud V. (2014) Tax Incentives for R\&D and Innovation: Demand Versus Effects]. Foresight-Russia, vol. 8, no 3, pp. 18-41.

Gokhberg L., Zaichenko S., Kitova G., Kuznetsova T. (2011) Nauchnaya politika: globalnyi kontekst i rossiiskaya praktika [Science policy: The global context and Russian practice], Moscow: HSE (in Russian).

Golikova V., Gonchar K., Kuznetsov B. (2012) Vliyanie eksportnoi deyatelnosti na tekhnologicheskie i upravlencheskie innovatsii rossiiskikh firm [Effect of export activity on technological and managerial innovations at Russian companies]. Russian Management Journal, vol. 10, no 1. Available at: http://www.rjm.ru/files/files3/2012/golikova_gonchar_kuznetsov_ rjm_1_12.pdf, accessed 28.11.2014 (in Russian).

Gonchar K.R. (2009) Innovatsionnoe povedenie sverkhkrupnykh kompaniy: lenivye monopolii ili agenty modernizatsii? [Innovative behavior of mega-companies: Lazy monopoly or agents of modernization?] (Preprint WP1/2009/02), Moscow: HSE (in Russian).

Government of the Russian Federation (2013) Plan meropriyatii ('dorozhnaya karta') v oblasti inzhiniringa i promyshlennogo dizaina (utverzhden rasporiazheniem Pravitelstva RF № 1300-p, 23.07. 2013 [Action Plan ('roadmap') in the field of engineering and industrial design (approved by the resolution no 1300-p, dated 23.07.2013] (in Russian).

HSE (2014a) Prognoz nauchno-tekhnologicheskogo razvitiya Rossii na period do 2030 goda [Russia Long-term S\&T Foresight until 2030], Moscow: HSE (in Russian).

HSE (2014b) Indikatory nauki: 2014. Statisticheskii sbornik [Science and Technology Indicators in the Russian Federation: 2014. Data Book], Moscow: HSE (in Russian).

IDC (2013) Rossiiskii rynok inzhenernogo PO prevysil 200 millionov dollarov [The Russian market of engineering software has exceeded \$200 million] (press release). Available at: http://idcrussia.com/ru/about-idc/press-center/56741-press-release, accessed 28.11.2014 (in Russian).

Idrisov A. (2011) Novaya industrializatsiya v Rossii: vozmozhnosti i riski [New Industrialization in Russia: Opportunities and Risks], Moscow: Strategy Partners. Available at: http://www.strategy.ru/UserFiles/File/presentations/Idrisov.pdf, accessed 28.11.2014 (in Russian).

Idrisov A., Grigoryev M. (2012) Novaya industrializatsiya v Rossii i tretiya promyshlennaya revolutsiya [New industrialization in Russia and the third industrial revolution], Moscow: Strategy Partners. Available at: http://www.strategy.ru/UserFiles/File/ presentations/Idrisov_AS 2012.pdf, accessed 28.11.2014 (in Russian).

Ivanov D., Kuzyk M., Simachev Y. (2012) Stimulirovanie innovatsionnoi deiatelnosti rossiiskikh proizvodstvennykh kompaniy: vozmozhnosti i ogranicheniya [Fostering Innovation Performance of Russian Manufacturing Enterprises: New Opportunities and Limitations]. Foresight-Russia, vol. 6, no 2, pp. 18-41 (in Russian).

Knyaginin V. (2011) Bazovaya gipoteza promyshlennogo forsaita [The basic hypothesis of industrial foresight]. Saint-Petersburg: Center for Strategic Research North-West. Available at: http://www.csr-nw.ru/upload/file_content_343.pdf, accessed 28.11.2014 (in Russian).

Kotsar Y. (2013) 3D-pechat stanovitsya meinstrimom [3D-printing becomes a mainstream]. Available at: http://www.gazeta.ru/ tech/2013/12/24_a_5817873.shtml, accessed 28.11.2014 (in Russian).

Labykin A. (0214b) Proizvodstvo rossiiskikh 3D-printerov spotykaetsya o stereoripy [Production of Russian 3D-printers stumbles on stereotypes]. Available at: http://expert.ru/2014/03/25/proizvodstvo-rossijskih-3d-printerov-spotyikaetsya-o-stereotipyi/, accessed 28.11.2014 (in Russian).

Labykin A. (2014a) Kompozity ukreplyaiut ekonomiku [Composites strengthen the economy]. Available at: http://expert. ru/2014/08/5/kompozityi-ukreplyayut-ekonomiku/, accessed 28.11.2014 (in Russian).

Laskina I. (2014) Rossiiskii rynok kompyuternogo inzhiniringa. Podvedenie itogov anketirovaniya (rezyume) [The Russian market of computer engineering. Survey results], Saint-Petersburg: Center for Strategic Research 'North-West'. Available at: http:// fea.ru/spaw2/uploads/files/2014_0710 \%D0\%9A\%D0\%BE\%D0\%BC\%D0\%BF\%D1\%8C\%D1\%8E\%D1\%82\%D0\%B5\%D1\% 80\%D0\%BD\%D1\%8B\%D0\%B9\%20\%D0\%B8\%D0\%BD\%D0\%B6\%D0\%B8\%D0\%BD\%D0\%B8\%D1\%80\%D0\%B8\%D0\%B D\%D0\%B3_\%D0\%9B\%D0\%B0\%D1\%81\%D0\%BA\%D0\%B8\%D0\%BD\%D0\%B0\%20\%D0\%98_.pdf, accessed 28.11.2014 (in Russian).

Povalko A. (2014) O sozdanii i razvitii inzhiniringovykh tsentrov na baze obrazovatelnykh organizatsii vysshego obrazovaniya. Itogi 2013 goda i plany na 2014-2016 gody [About the establishment and development of engineering centers at the educational institutes of higher education. Results of 2013 and plans for 2014-2016], Moscow: Ministry of Education and Science of the Russian Federation. Available at: http://test.akrupin.mptdev.dev.armd.ru/common/upload/files/docs/preza_1. pdf, accessed 28.11.2014 (in Russian).

Russian Technology Agency (2014) Razvitie industrii robototekhniki v Rossiiskoi Federatsii [The development of robotics industry in the Russian Federation], Moscow: Russian Technology Agency. Available at: http://rta.gov.ru/1.pdf, accessed 28.11.2014 (in Russian).

Saprykin D. (2014) Rossiiskii rynok i proizvodstvo lazernogo tekhnologicheskogo oborudovaniya v kontekste razvitiya stankostroeniya [The Russian market and the production of laser processing equipment in the context of machine tool development]. Laser-Inform, no 1 (in Russian).

Simachev Y. Kuzyk M., Kuznetsov B., Pogrebnyak E. (2014) Promyshlennaya politika v Rossii v 2000-2013: institutsionalnye osobennosti i osnovnye uroki [Industrial policy in Russia in 2000-2013: Institutional features and key lessons]. Rossiiskaya ekonomika v 2013. Tendentsii i perspektivy [The Russian economy in 2013. Trends and Prospects], no 35, Moscow: Gaidar Institute Publishing, pp. 417-453. Available at: http://www.iep.ru/files/RePEc/gai/gbooks/RussianEconomyIn2013issue35 ru.pdf, accessed 28.11.2014 (in Russian).

Voronina Y. (2012) Sami sdelaem [Do ourselves]. Russian business newspaper - industrial review. Available at: http://www. rg.ru/2012/09/18/materiali.html, accessed 28.11.2014 (in Russian).

Wohlers Associates (2013) Additive Manufacturing and 3D Printing State of the Industry (Annual Wohlers Report), Fort Collins, CO: Wohlers Associates.

Yakovlev A. (2014) Russian modernization: Between the need for new players and the fear of losing control of rent sources. Journal of Eurasian Studies, vol. 5, no 1, pp. 10-20. 